\title{
Mobbing szkolny wśród uczniów z zaburzeniami w komunikowaniu się - percepcja zjawiska i potencjalne kierunki działań
}

Bullying among students with communication disorders - perception of the phenomenon and recommended actions

\footnotetext{
Słowa kluczowe: dokuczanie, jąkanie, logopeda, mobbing szkolny, nauczyciel, zaburzenia w komunikowaniu się, zapobieganie
}

Keywords: bullying, stuttering/stammering, speech-language therapist/pathologist (SLT/SLP), teacher, communication disorders, prevention

\section{Wprowadzenie}

Mobbing szkolny, inaczej przemoc rówieśnicza, agresja szkolna lub nękanie, bywa też określany czasem jako bullying [Pyżalski, 2012; Węsierska i wsp., 2015]. Kryteria, które pozwalają odróżnić mobbing od innych zachowań agresywnych, to przede wszystkim [Olweus, 2007; Rigby, 2010]:

1) powtarzalność - nękanie ofiary powtarza się w czasie;

2) nierównowaga sił - mobbing nie jest konfliktem dwóch osób o podobnej sile; w sytuacji mobbingu ofiara stoi zwykle na słabszej pozycji; słabość ta nie polega jedynie na mniejszej sile fizycznej ofiary, w wielu przypadkach nierównowaga sił ma podłoże psychiczne, polega na przykład na braku zdolności do obrony, niższej pewności siebie czy trudnościach w wypowiadaniu się; dzieci, które

\footnotetext{
* Uniwersytet Śląski w Katowicach, Wydział Humanistyczny, Instytut Językoznawstwa, pl. Sejmu Śląskiego 1, 40-032 Katowice, e-mail: katarzyna.wesierska@us.edu.pl. Centrum Logopedyczne w Katowicach, e-mail: kwesierska@centrumlogopedyczne.com.pl, https://orcid.org/0000-0001-6378-9350
} 
znęcają się nad innymi, używają swojej przewagi do kontroli lub wyrządzenia krzywdy;

3) cykliczność zachowań agresywnych - liczba zachowań agresywnych wzrasta, między nimi mogą następować okresy względnego spokoju;

4) utrwalone role - w sytuacji mobbingu, w odróżnieniu od incydentalnej agresji, zazwyczaj nie dochodzi do zamiany ról ofiary i agresora.

Można wyróżnić różne formy mobbingu szkolnego [Gebauer, 2007]:

1) mobbing fizyczny (ang. physical), np. popychanie, kopanie, bicie;

2) mobbing werbalny (ang. verbal), np. przezywanie, obraźliwy język, wyzwiska;

3) mobbing relacyjny (ang. relational), np. rozsiewanie plotek, wykluczenie z grupy społecznej, poniżanie;

4) mobbing elektroniczny, tzw. cyberprzemoc (ang. cyber-bullying), np. wysyłanie SMS-ów, umieszczanie krzywdzących informacji na portalach społecznościowych, wykorzystanie innej technologii, aby anonimowo, bez osobistego kontaktu, wyrządzić krzywdę.

Ze zjawiskiem tym związane są różne podmioty: sprawcy mobbingu, osoby znęcające się (ang. bullies), ofiary (ang. victims) oraz osoby postronne, świadkowie (ang. bystanders). Co ważne, zarówno sprawcy, jak i ofiary mogą występować w podwójnej roli - sprawcy-ofiary (ang. bully-victims) [Miller, Lowen, 2012]. Mobbing szkolny jest groźnym zjawiskiem społecznym, które może powodować długofalowe konsekwencje dla wszystkich stron w nim uczestniczących [Card, Hodges, 2008].

Próbę oszacowania skali zjawiska podjęto w międzynarodowych badaniach HBSC (Health Behavior of School-Children). W Polsce rozpowszechnienie mobbingu szkolnego analizowano w ramach programu "Szkoła bez przemocy”. Badacze zgadzają się co do tego, że problem ten w sposób bezpośredni dotyka co najmniej kilkunastu procent młodzieży szkolnej [Rigby, 2010]. Chłopcy deklarują bycie ofiarą mobbingu częściej niż dziewczęta, a młodsi uczniowie częściej niż starsi [Ostrowska, Surzykiewicz, 2005]. Jako grupę szczególnego ryzyka wymienia się również dzieci ze specjalnymi potrzebami edukacyjnymi (SPE). Są one znacznie bardziej narażone na ryzyko mobbingu szkolnego niż dzieci określone jako prawidłowo rozwijające się [Mishna, 2003; Little, 2004; Hershkowitz, Lamb, Horowitz, 2007]. W grupie tej znajdują się między innymi dzieci niepełnosprawne, $\mathrm{z}$ całościowymi lub sprzężonymi zaburzeniami rozwojowymi (np. autyzmem, zespołem Aspergera), cierpiące na zespół nadpobudliwości psychoruchowej (ADHD). Pewne objawy towarzyszące czasem niepełnosprawności (takie jak brak siły fizycznej, izolacja społeczna, zaburzone lub utrudnione relacje z innymi) mogą być potencjalnymi czynnikami sprzyjającymi wiktymizacji [Plichta, 2010].

Pewne czynniki ryzyka mobbingu wiążą się z cechami i zachowaniami dziecka. Należą do nich między innymi: wrażliwość, nieśmiałość, niepewność i ostrożność $\mathrm{w}$ kontaktach $\mathrm{z}$ innymi, słabe relacje $\mathrm{z}$ rówieśnikami, nieumiejętność nawiązywania przyjaźni, wysoki poziom lęku, bierność, uległość, a szczególnie brak umiejętności obrony w sytuacjach przemocy, płaczliwość, niska samoocena, negatywne 
nastawienie do stosowania przemocy, słabość lub niska sprawność fizyczna, nieśmiałość lub posiadanie jakiejś cechy wyróżniającej dziecko na tle grupy, a także wrażliwość na punkcie cechy [Olweus, 2007; O’Moore, Minton, 2008; Rigby, 2010]. Można zatem założyć, że doświadczanie przez dziecko utrudnień w komunikowaniu się, takich jak na przykład jąkanie, może być potencjalnym czynnikiem wzmacniającym ryzyko stania się ofiarą mobbingu szkolnego. Potwierdziły to wyniki badań prowadzonych między innymi w Australii, Kanadzie, Stanach Zjednoczonych, a także w Polsce [Langevin i wsp., 1998; Blood i wsp., 2010; Erickson, Block, 2013; Węsierska i wsp., 2015]. Udowodniono, że zaburzenia w komunikowaniu się są postrzegane raczej negatywnie przez inne dzieci już na wczesnych etapach edukacji i w zawiązku z tym podlegają społecznej stygmatyzacji. Jak wykazały badania prowadzone w Australii, już dzieci w wieku przedszkolnym bywają przez rówieśników wyśmiewane z powodu ich problemów z wypowiadaniem się [Langevin, Packman, Onslow, 2010]. W szkole podstawowej im dzieci są starsze, tym częściej mogą spotkać się z przejawami dokuczania z powodu zaburzeń w komunikowaniu się (np. takich jak jąkanie, specyficzne zaburzenie rozwoju językowego - SLI czy utrudnienia w komunikowaniu występujące u dzieci ze spektrum autyzmu) [Little, 2001; Davis, Howell, Cooke, 2002; Savage, 2005; Lindsay, Dockrell, Mackie, 2008].

W celu zapobiegania mobbingowi szkolnemu od lat podejmowane są różne działania. Prekursorem antymobbingowych programów zaradczych był norweski badacz Dan Olweus. Stworzył on ramowy program zapobiegania zachowaniom agresywnym w szkole, którego celem jest ograniczenie lub całkowite wyeliminowanie mobbingu w środowisku edukacyjnym [Olweus, 1991]. Istotną cechą tego oraz innych, tworzonych na całym świecie programów jest wdrażanie różnych form działań pro- i reaktywnych, polegających między innymi na edukowaniu uczniów, nauczycieli, personelu szkolnego i rodziców na temat mobbingu szkolnego. Pierwszym etapem tworzenia programu przeciwdziałania agresji jest podnoszenie świadomości na ten temat [Rigby, 2010]. Proponuje się na przykład organizację specjalnych dni poświęconych edukacji na temat przemocy w szkole, wzmożonych dyżurów nauczycieli w czasie przerw, a także utworzenie telefonu zaufania ułatwiającego komunikację uczniów z pedagogami i zgłaszanie przypadków mobbingu. Jako istotne formy działań wskazuje się również programy edukacyjne dla rodziców, zwiększające ich kompetencje, uczenie dzieci i nastolatków podstawowych umiejętności psychologicznych i społecznych, prowadzenie przez nauczycieli warsztatów poświęconych relacjom interpersonalnym [Greene, 2014].

W procesie zapobiegania mobbingowi wśród dzieci z problemami logopedycznymi podkreśla się szczególną rolę rodzica. To on zna dziecko najlepiej i może szybko zauważyć niepokojące objawy w zachowaniu, ma też możliwość rozmowy z dzieckiem na temat przemocy w szkole. Dzieci często nie mają wiedzy na temat mobbingu, myślą, że same są winne złego traktowania, że informowanie dorosłych tylko pogłębi problem. Brak wiedzy sprawia, że mobbing jest zbyt późno zauważany, 
a ofiara nie wie, gdzie szukać pomocy [Little, 2004]. Bardzo istotne jest szkolenie pedagogów i nauczycieli, aby byli skutecznym wsparciem dla dziecka doświadczającego utrudnień w komunikowaniu się i z tego powodu mogącego paść ofiarą mobbingu szkolnego. W ramach takich kursów nauczyciel opanowuje umiejętności, które umożliwiają przeprowadzanie w odpowiedni sposób rozmów z uczniami. Warto zauważyć, że pedagog jest często wzorem, zwłaszcza dla dorastających i poznających świat dzieci, ważne zatem, aby propagował odpowiednie ścieżki poprawnej komunikacji wśród uczniów [Kuros, Węsierska, 2013].

Problem mobbingu to również problem braku akceptacji dla odmienności. Celem działań pedagogizacyjnych jest zwiększenie świadomości, wrażliwości i budowanie klimatu akceptacji dla inności [Langevin, 2015]. Edukacja społeczeństwa na temat problemów logopedycznych może zwiększyć ich akceptację, a w przypadku zespołu klasowego pozytywnie wpłynąć na jego reakcję, ponieważ daje możliwość bliższego poznania omawianego problemu [Węsierska, 2012]. Przykładem programu antymobbingowego stworzonego z myślą o dzieciach jąkających się, ale adresowanego do całych społeczności szkolnych, jest opracowany przez kanadyjską badaczkę i terapeutkę Marilyn Langevin Teasing and Bullying: Unacceptable Behaviour. The TAB Program [2000]. Pozwala on wprowadzać zasady edukacji włączającej, wykorzystując jąkanie jako formę inności, która nie może być źródłem dyskryminacji. Ostatnie lata przynoszą coraz powszechniejsze zastosowanie tego typu działań prewencyjnych w placówkach edukacyjnych na całym świecie [Smith, Pepler, Rigby, 2004]. Podejmowanie tego typu działań wydaje się jednym z ważniejszych zadań, które powinny być inicjowane w ramach profilaktyki logopedycznej.

W dalszej części artykułu zreferowane zostaną wyniki dwóch projektów badawczych związanych z mobbingiem szkolnym wśród dzieci z problemami logopedycznymi. Pierwszy projekt dotyczył sondowania opinii logopedów i nauczycieli na temat zjawiska dokuczania dzieciom, które zmagają się z jakimkolwiek problemem logopedycznym. Natomiast drugi projekt badawczy odnosił się do możliwości zastosowania warsztatów antymobbingowych dla dzieci jąkających się i ich rodziców w celu poprawy jakości funkcjonowania tych dzieci w środowisku edukacyjnym. W podsumowaniu tego artykułu sformułowano wnioski praktyczne na podstawie analizy literatury przedmiotu i wyników uzyskanych w obu projektach badawczych.

\section{Projekt I: Sondowanie opinii nauczycieli i logopedów na temat występowania mobbingu szkolnego wśród uczniów z problemami logopedycznymi}

Celem opisywanego poniżej badania sondażowego prowadzonego wśród nauczycieli i logopedów było rozpoznanie ich opinii na temat doświadczeń związanych z mobbingiem szkolnym wśród dzieci zmagających się z zaburzeniami w komunikowaniu 
się. Za zaburzenia w komunikowaniu się uznano te, z którymi najczęściej zmagają się uczniowie szkół podstawowych: opóźniony rozwój mowy, wady wymowy, specyficzne zaburzenie rozwoju językowego (SLI), zaburzenia płynności mowy (jąkanie lub giełkot) czy problemy w komunikowaniu się występujące w spektrum autyzmu. W badaniu sondowano umiejętność rozpoznawania pierwszych oznak mobbingu oraz poziom świadomości respondentów na ten temat, a także ich gotowość do podejmowania działań zaradczych w tym zakresie. W badaniu ankietowym wzięły udział dwie grupy respondentów: logopedzi $(n=59)$ i nauczyciele $(n=53)$. Badani respondenci zatrudnieni byli w placówkach edukacyjnych - szkołach podstawowych oraz poradniach psychologiczno-pedagogicznych. Badania przeprowadzono w formie papierowej wśród osób zatrudnionych w placówkach edukacyjnych oraz elektronicznej, głównie wśród logopedów - pozwoliło to dotrzeć do większego grona specjalistów.

W obu grupach badawczych wśród respondentów dominowały kobiety $(98,3 \%$ w grupie logopedów i 83\% w grupie nauczycieli). Grupę logopedów stanowili specjaliści nieco młodsi (do 35 lat - 52,5\%, do 45 lat - 33,9\% i do 55 lat - 13,6\%, żaden z logopedów nie przekroczył 56 lat). Wśród nauczycieli można było zaobserwować większe zróżnicowanie wiekowe (do 34 lat - 26,4\%, do 45 lat - 39,6\%, do 55 lat - 26,4\% i powyżej 56 lat - 7,5\% respondentów). Staż pracy w zawodzie logopedy lub nauczyciela zestawiono w tabeli 1 . Respondenci w obu grupach wywodzili się zarówno z terenów miejskich (59,3\% logopedów i 77,4\% nauczycieli), jak i wiejskich (40,7\% logopedów i 22,6\% nauczycieli). Badanie prowadzono w dwóch województwach - śląskim oraz małopolskim.

Tabela 1. Staż pracy w obu grupach respondentów $(n=112)$

\begin{tabular}{|l|c|c|c|c|}
\hline \multirow{2}{*}{ Staż pracy } & \multicolumn{2}{|c|}{ Logopedzi $(n=59)$} & \multicolumn{2}{c|}{ Nauczyciele $(n=53)$} \\
\cline { 2 - 5 } & Liczba & Procent & Liczba & Procent \\
\hline Poniżej 5 lat & 26 & 44,1 & 14 & 26,4 \\
\hline Od 5 do 10 lat & 6 & 10,2 & 6 & 11,3 \\
\hline Powyżej 10 lat & 27 & 45,8 & 33 & 62,3 \\
\hline
\end{tabular}

Badanie sondażowe przeprowadzono z użyciem autorskiego kwestionariusza ankiety ( $w$ dwóch zbliżonych treściowo wersjach - dla nauczycieli i dla logopedów). Podstawowa wersja ankiety (wspólna dla obu grup) składała się z dwunastu pytań: zamkniętych, otwartych oraz jedno- i wielokrotnego wyboru. W ankiecie skierowanej do logopedów znalazło się jedno dodatkowe pytanie na temat reakcji dzieci uczęszczających na terapię, które mogą być ofiarami mobbingu. Z kolei w ankiecie skierowanej do nauczycieli dodano dwa szczegółowe pytania dotyczące obserwacji nauczyciela na temat występowania zjawiska mobbingu w szkole, w której jest zatrudniony. 
Większość respondentów w obu grupach przyznała, że spotkała się w swojej praktyce zawodowej ze zjawiskiem mobbingu szkolnego (twierdzącej odpowiedzi w tym zakresie udzieliło aż 84,7\% sondowanych logopedów i 86,8\% nauczycieli). W grupie logopedów $88,1 \%$ przyznało, że uczeń zgłosił im problem dokuczania, znęcania (23,7\% oszacowało, że miało to miejsce często, a $64,4 \%$ sporadycznie). W przypadku nauczycieli takie zgłoszenia miały miejsce aż u 90,5\% respondentów (jako częste zadeklarowało je $24,5 \%$ badanych, a jako sporadyczne $66 \%$ ). Tabela 2 prezentuje trzy najbardziej typowe formy mobbingu szkolnego ze wskazaniem, jak często logopedzi i pedagodzy mieli do czynienia z tymi zjawiskami w swojej praktyce zawodowej.

Tabela 2. Rozpowszechnienie poszczególnych form mobbingu szkolnego w percepcji respondentów $(n=112)$

\begin{tabular}{|l|c|c|c|c|c|c|c|c|}
\hline \multirow{2}{*}{ Formy mobbingu szkolnego } & \multicolumn{6}{|c|}{$\begin{array}{c}\text { Stopień nasilenia według logopedów - L ( } n=59) \\
\text { i nauczycieli - N ( } n=53 \text { ) (w proc.) }\end{array}$} \\
\cline { 2 - 10 } & \multicolumn{2}{|c|}{ Nigdy } & Czasami & \multicolumn{2}{c|}{ Często } & \multicolumn{2}{c|}{ Bardzo często } \\
\cline { 2 - 9 } & $\mathrm{L}$ & $\mathrm{N}$ & $\mathrm{L}$ & $\mathrm{N}$ & $\mathrm{L}$ & $\mathrm{N}$ & $\mathrm{L}$ & $\mathrm{N}$ \\
\hline $\begin{array}{l}\text { Przemoc psychiczna (wyśmiewanie, } \\
\text { obrażanie, przezywanie, obgadywanie, } \\
\text { izolowanie zżycia klasy) }\end{array}$ & 6,8 & 24,5 & 66,1 & 47,2 & 20,3 & 28,3 & 6,8 & 9,4 \\
\hline $\begin{array}{l}\text { Przemoc fizyczna (popychanie, kopanie, } \\
\text { szturchanie) }\end{array}$ & 11,9 & 11,3 & 74,6 & 66,0 & 11,9 & 22,6 & 1,7 & 0,0 \\
\hline $\begin{array}{l}\text { Cyberprzemoc (dokuczanie w sieci, } \\
\text { wyzwiska rzucane na profilach } \\
\text { społecznościowych) }\end{array}$ & 45,8 & 50,9 & 47,5 & 34,0 & 6,8 & 15,1 & 0,0 & 0,0 \\
\hline
\end{tabular}

Źródło: badania własne.

Odpowiedzi udzielane przez logopedów i nauczycieli wykazały, że najczęściej obserwowana była przez nich przemoc psychiczna, następnie fizyczna, a najrzadziej mobbing w sieci. Analizując z kolei odpowiedzi pod kątem częstości obserwowanych czy zgłaszanych logopedom i nauczycielom form przemocy, należy zwrócić uwagę na duży stopień podobieństwa między grupami. Odpowiedzi udzielane w obu grupach respondentów zostały poddane analizie statystycznej z wykorzystaniem testu zgodności $\chi^{2}$. Różnice, które ujawniły się w odpowiedziach między obu grupami, nie były istotne statystycznie $(p>0,05)$.

Respondentów zapytano również o to, w jakim wieku dzieci najczęściej sobie dokuczają (rysunek 1). W obu grupach najpowszechniej wskazywanym przedziałem wiekowym były klasy od IV do VI szkoły podstawowej (ten zakres wskazało 52,5\% logopedów i 67,9\% nauczycieli). W następnej kolejności wskazano w obu grupach klasy VII-VIII (32,2\% logopedów i 24,5\% nauczycieli). Okres nauczania wczesnoszkolnego - klasy I-III - wybrało zaledwie 6,8\% logopedów i 7,5\% nauczycieli. Z kolei grupę określoną w badaniu jako „starsza młodzież” (okres nauki w liceum, technikum) wskazało 8,5\% logopedów. Co ciekawe, na nią jako tę, w której najczęściej można zaobserwować zjawisko mobbingu szkolnego, nie wskazał żaden z nauczycieli. 


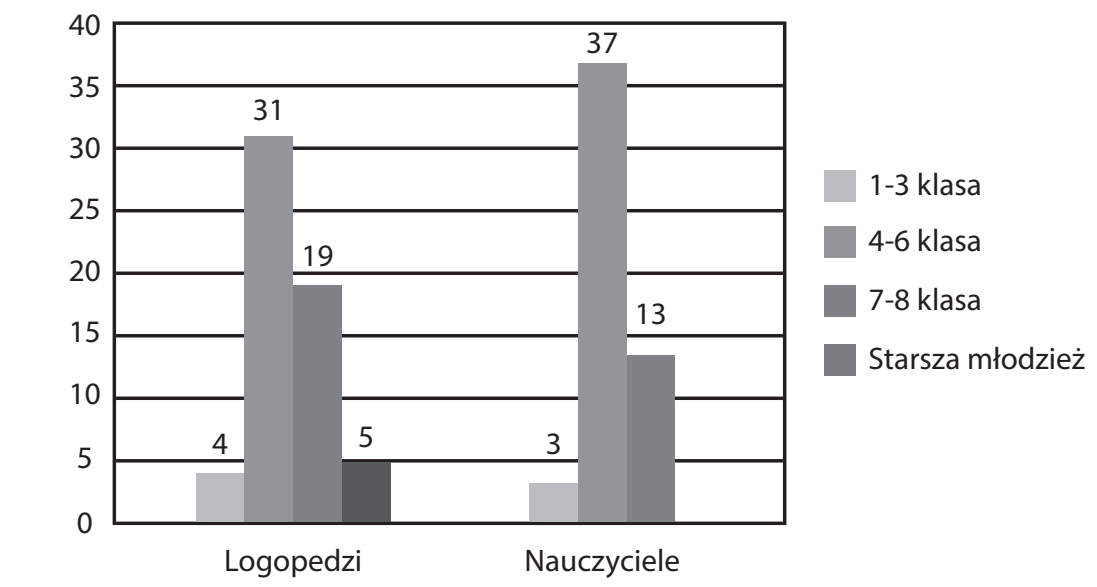

Rysunek 1. Okres szkolny, w którym najczęściej obserwowane jest występowanie mobbingu w opiniach logopedów $(n=59)$ i nauczycieli $(n=53)$

Źródło: badania własne.

Respondenci zostali również poproszeni o wskazanie doświadczeń, z którymi zmagają się dzieci - ofiary mobbingu szkolnego. Do najczęściej wskazywanych odpowiedzi w obu grupach respondentów należały: bycie przedmiotem kpin ze strony innych dzieci, osamotnienie (brak dobrego kolegi, przyjaciela), posiadanie nacechowanych negatywnie przezwisk nadawanych przez rówieśników, bycie szturchanym, popychanym, kopanym czy zaczepianym. Z kolei zachowania, reakcje najczęściej obserwowane w obu grupach respondentów, typowe dla sprawców mobbingu, to: celowe mówienie rzeczy, które mogą zranić innych, wyśmiewanie innych, grożenie im, popychanie, niszczenie przedmiotów należących do innych osób, impulsywność, manifestowanie niskiego progu frustracji oraz buntu i negatywnego nastawienia do szkoły, nauczycieli, znajomych, prezentowanie wysokiego mniemania o sobie, a także innych zachowań świadczących o społecznym niedostosowaniu (np. spożywanie alkoholu i innych używek, wdawanie się w bójki, kradzieże itp.).

Niepokoić może, że w obu grupach respondentów większość badanych, bo aż 66,1\% logopedów i 62,3\% nauczycieli, przyznała, że na studiach nie była przygotowywana do radzenia sobie ze zjawiskiem mobbingu i takimi typami zachowań, jak agresja fizyczna, psychiczna czy też cyberbullying. Należy jednak podkreślić, że $61 \%$ badanych logopedów i aż 75,5\% nauczycieli, którzy wzięli udział w badaniu, potwierdziło, że w placówkach, w których są zatrudnieni, wdrażane są jakieś formy profilaktyki dotyczące zapobiegania mobbingowi szkolnemu. Co więcej, w obu grupach respondentów niemal wszyscy badani wskazali, że w szkołach powinny być wdrażane profilaktyczne programy/kampanie antymobbingowe mające na celu zapobieganie temu zjawisku - takiej odpowiedzi udzielili wszyscy sondowani logopedzi i 96,2\% nauczycieli (dwie osoby wskazały odpowiedź negatywną, nie podając uzasadnienia). Respondenci w następujący sposób komentowali i uzasadniali podejmowanie tego typu działań: „dzieci powinny wiedzieć, 
że są pewne konsekwencje złego postępowania, a jednocześnie powinny wiedzieć, jak bronić się przed mobbingiem, natomiast nauczyciele i rodzice powinni rozpoznawać dziecko prześladowane i odpowiednio reagować”; „zjawisko to coraz częściej występuje w środowisku szkolnym”; „problem występuje u coraz młodszych dzieci i nasila się”; „każdy uczeń w szkole powinien czuć się bezpiecznie”; „programów antymobbingowych jest zdecydowanie za mało, a problem istnieje”; „uczniowie powinni się nauczyć, że nie są najważniejsi, ale również inne dzieci i ich uczucia”; „lepiej działać profilaktycznie”; „profilaktyka powinna być działaniem długofalowym, a nie jednorazowym”.

Ankietowani zostali również poproszeni o wskazanie, jaką formę powinny mieć programy antymobbingowe. Udzielone przez nich odpowiedzi zaprezentowano na rysunku 2. Respondenci mogli wybrać więcej niż jedną odpowiedź.

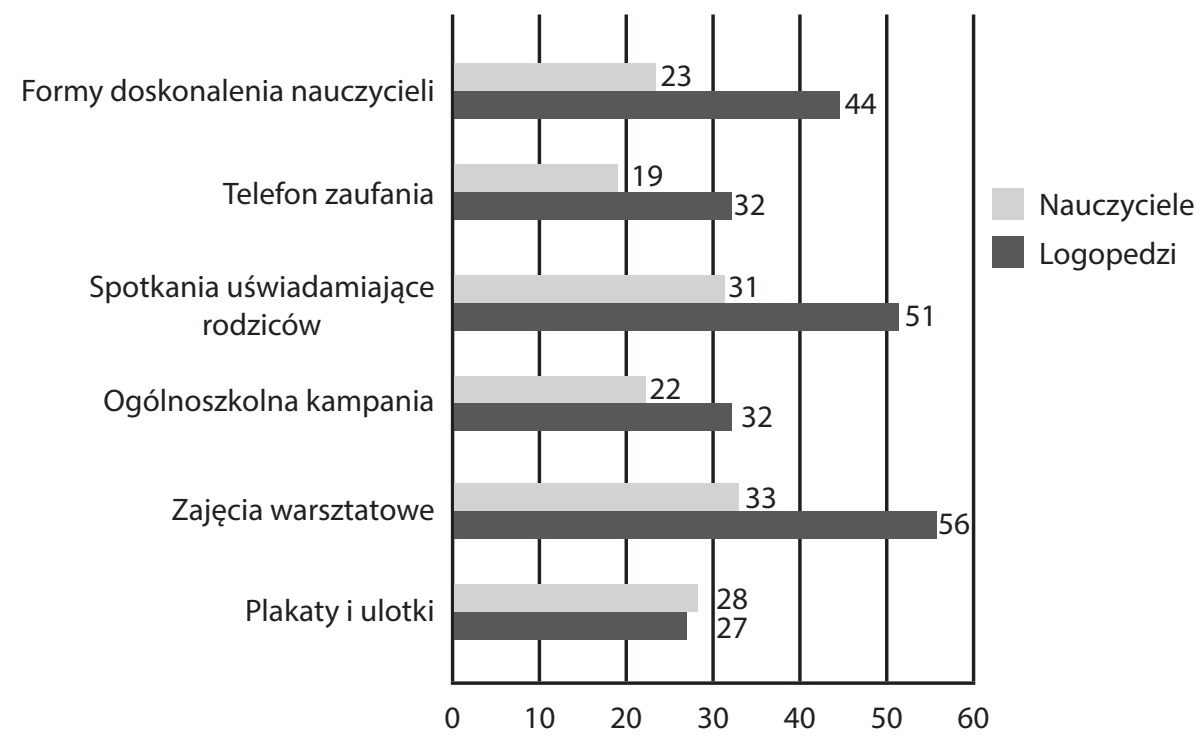

Rysunek 2. Rekomendowane formy działań antymobbingowych w opiniach logopedów $(n=59)$ i nauczycieli $(n=53)$

Źródło: badania własne.

Interesująco prezentują się opinie respondentów na temat tego, czy dzieci zmagające się z zaburzeniami w komunikowaniu się częściej niż inne doświadczają mobbingu szkolnego. W tej kwestii ujawniły się najbardziej widoczne różnice (nie są one jednak istotne statystycznie). Na to pytanie pozytywnej odpowiedzi udzieliło 37,3\% logopedów i $28,3 \%$ nauczycieli. Negatywnie z kolei odpowiedziało 35,5\% logopedów i 49,1\% nauczycieli. Wyrobionego zdania na ten temat nie miało $27,1 \%$ logopedów i 22,6\% nauczycieli.

Istotne statystycznie różnice między obu grupami ujawniły się wyłącznie w udzielonych przez nich odpowiedziach na pytania dotyczące stopnia nasilenia poszczególnych form mobbingu szkolnego, którego doświadczają dzieci zmagające się z problemami w komunikowaniu się. Dla przykładu: na pytanie, jak często dzieci doświadczają 
agresji fizycznej w postaci popychania, przewracania, uderzania itp., logopedzi - mając do wyboru odpowiedzi: nigdy, czasami, często, bardzo często - wybierali czasami, podczas gdy w grupie nauczycieli najczęściej wybieraną odpowiedzią było nigdy $\left(\chi^{2}(2)=15,48\right.$, $p>0,001)$. W przypadku pytania o obgadywanie logopedzi wybierali przede wszystkim odpowiedź często, a nauczyciele nigdy $\left(\chi^{2}(3)=22,61, p>0,001\right)$. Podobne wskazania $\mathrm{w}$ obu grupach miały miejsce w przypadku pytania o przedrzeźnianie $\left(\chi^{2}(3)=18,37\right.$, $p>0,001)$. Także w pytaniu o to, jak często dzieci z zaburzeniami w komunikowaniu są przezywane przez inne dzieci, nauczyciele udzielali przede wszystkim odpowiedzi nigdy, podczas gdy logopedzi wybierali odpowiedzi: czasami, często lub bardzo często $\left(\chi^{2}(3)=16,39, p=0,001\right)$. Na pytanie o to, czy dzieci z zaburzeniami w komunikowaniu się są wyśmiewane, ze strony nauczycieli podały odpowiedzi, że ma to miejsce czasami, podczas gdy logopedzi odpowiadali bardzo często $\left(\chi^{2}(3)=18,39, p=0,001\right)$. Wydaje się, że te istotne rozbieżności między ocenami logopedów i nauczycieli ujawnione w odpowiedziach udzielanych w tej sekcji pytań mogą mieć związek z rodzajem kontaktów, jakie mają z uczniami logopedzi (najczęściej indywidualne - podczas zajęć logopedycznych) i nauczyciele (najczęściej w grupie - podczas lekcji).

Logopedów zapytano również o to, jaki wpływ na terapię logopedyczną i ogólne zachowanie dziecka może mieć doświadczanie mobbingu szkolnego (rysunek 3). Udzielając odpowiedzi na to pytanie, respondenci mogli wybrać więcej niż jedną odpowiedź. Dodatkowo trzech logopedów stwierdziło, że konsekwencją mobbingu może być unikanie logopedy, na przykład na szkolnych korytarzach. Opinie respondentów wyraźnie wskazują, że doświadczanie mobbingu szkolnego może być istotnym czynnikiem utrudniającym osiąganie pozytywnych efektów w terapii logopedycznej.

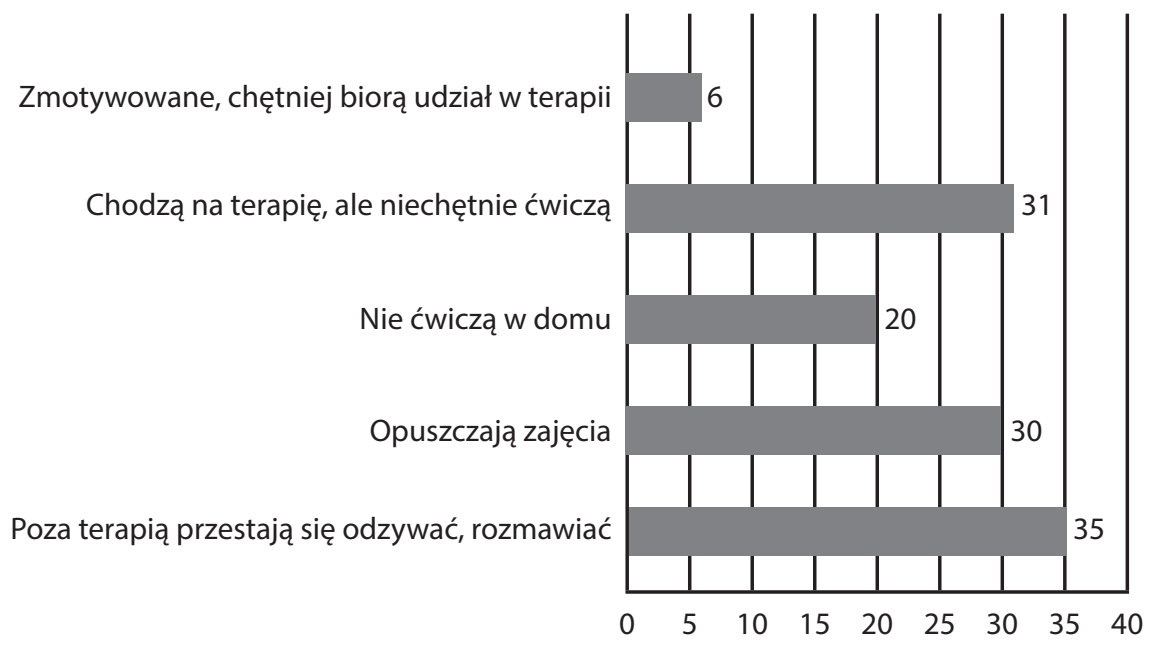

Rysunek 3. Wpływ mobbingu szkolnego na dzieci z zaburzeniami w komunikowaniu się w opiniach logopedów $(n=59)$ 
Z kolei grupę nauczycieli poproszono dodatkowo o wyrażenie opinii na temat potencjalnych miejsc w zatrudniających ich placówkach, w których zaobserwowali występowanie mobbingu szkolnego. Aż 80,8\% ankietowanych potwierdziło, że miało okazję poczynić takie obserwacje. Miejsca, w których zauważyli występowanie zjawiska mobbingu, to najczęściej szkolny korytarz, a także szatnie, toalety, świetlice, boiska szkolne. Najrzadziej takie negatywne zdarzenia miały miejsce w klasach szkolnych, co można tłumaczyć stałą obecnością nauczyciela.

Większość biorących udział w tym badaniu - zarówno logopedów, jak i nauczycieli - uznała, że problem mobbingu w szkołach istnieje, a jego zakres się rozszerza. Z opinii respondentów wynika, że problemy w komunikowaniu się nie są jego najczęstszą przyczyną. W opiniach logopedów i nauczycieli mobbing szkolny jest najbardziej rozpowszechniony wśród uczniów ostatnich klas szkoły podstawowej. Niestety, znaczna większość nauczycieli i logopedów nie była przygotowywana na studiach do radzenia sobie z tym zjawiskiem. W szkołach, w których zatrudnieni byli respondenci, zazwyczaj były wdrażane jakieś formy profilaktyki, jednakże ankietowani podkreślali, że nauczyciele oraz rodzice powinni przejść dodatkowe przeszkolenie mające na celu zapoznanie się ze specyfiką zjawiska, aby byli w stanie w odpowiedni i szybki sposób zareagować na niepokojące objawy u dziecka oraz mu pomóc. Z punktu widzenia skuteczności i jakości opieki logopedycznej na terenie placówek edukacyjnych angażowanie się logopedów w różne formy działań profilaktycznych o charakterze antymobbingowym wydaje się jak najbardziej uzasadnione i potrzebne.

\section{Projekt II: Warsztaty antymobbingowe dla dzieci jąkających się i ich rodziców}

Przykładem działania, które może być podejmowane przez logopedów, są warsztaty antymobbingowe dla dzieci jąkających się i ich rodziców, które zostały wdrożone na Uniwersytecie Śląskim w Katowicach w ramach zajęć LogoLAB ${ }^{1}$. Cykl organizowanych comiesięcznie zajęć warsztatowych „Oswajamy jąkanie! Wzmacnianie u dzieci i ich rodziców poczucia sprawstwa w radzeniu sobie z jąkaniem" daje dzieciom jąkającym się i ich rodzicom czy opiekunom możliwość skorzystania z bezpłatnej formy wsparcia logopedycznego w zakresie: rozwijania kompetencji interpersonalnych, poszerzania wiedzy na temat komunikowania się i jąkania, wzmacniania ich samooceny oraz umiejętności radzenia sobie w trudnych sytuacjach komunikacyjnych, w tym także związanych z mobbingiem szkolnym. Uczestnicy zajęć mogą skonfrontować własne doświadczenia z doświadczeniami innych osób zmagających

1 Więcej informacji na temat LogoLAB oraz samych zajęć warsztatowych dla dzieci jąkających się i ich rodziców można znaleźć na stronie: http://www.zpm.us.edu.pl/logolab/ 
się z podobnymi problemami, a także skorzystać ze wsparcia oferowanego przez specjalistów i innych uczestników procesu grupowego, w tym wolontariuszy (studentów logopedii) oraz osób jąkających się (członków grup samopomocowych) i jąkających się specjalistów (logopedów, terapeutów).

W ramach tego cyklu spotkań zostały zorganizowane warsztaty antymobbingowe, oddzielnie dla rodziców (17 osób) i dla dzieci jąkających się (12 osób). Warsztaty w grupie rodziców polegały na przeprowadzeniu interaktywnej prezentacji „Przeciwdziałanie mobbingowi wśród dzieci jąkających się - rola rodzica”. Treści, które zawierała ta prezentacja, to przede wszystkim: najważniejsze informacje o mobbingu szkolnym, charakterystyczne cechy ofiary mobbingu szkolnego, zachowania mogące świadczyć o byciu ofiarą przemocy, techniki zaradcze i zapobiegawcze. Informacje podane w prezentacji zostały wybrane tak, aby rodzice uzyskali możliwie jak najpełniejszą wiedzę o zjawisku, mogli określić, czy ich dziecko znajduje się w grupie ryzyka, poznali, jakie istnieją zależności między jąkaniem i mobbingiem szkolnym, a także dowiedzieli się, jak zapobiegać mobbingowi lub - jeśli to konieczne - jak reagować, gdy dziecko doświadcza dokuczania w szkole. Rodzice biorący udział w warsztatach zostali poproszeni o wypełnienie ankiet przed warsztatami i po ich zakończeniu. $\mathrm{W}$ ankietach wypełnianych przed warsztatami rodzice deklarowali, że mają niewielkie poczucie sprawczości w zapobieganiu mobbingowi szkolnemu. Jako główne źródła wiedzy na temat przemocy szkolnej wymieniali internet i znajomych. Znaczna większość twierdziła, że nie wie, jak zareagować w sytuacji, kiedy ich dziecko stanie się ofiarą przemocy szkolnej. Z kolei po zakończeniu warsztatów antymobbingowych wypowiedzi rodziców $w$ ankietach uległy zmianie i świadczyły o tym, że zyskali oni większe poczucie sprawczości. Respondenci w tej ankiecie byli $\mathrm{w}$ stanie wymienić odpowiednie sposoby reagowania na przejawy mobbingu w szkole oraz potencjalne zasady zapobiegania temu zjawisku. Potrafili poprawnie podać objawy w zachowaniu dziecka, które mogłyby świadczyć, że jest ono ofiarą mobbingu, a także źródła wiarygodnej wiedzy na ten temat. Wydaje się, że taka jednorazowa forma wsparcia dla rodziców może być istotnym czynnikiem zmiany, ponieważ pozwala kształtować u nich postawy proaktywne, przygotowuje ich do umiejętnego reagowania na potencjalny problem i skutecznego wspierania dziecka w momencie, gdy doświadczałoby ono dokuczania ze strony kolegów.

Podobne tematycznie warsztaty przeprowadzono w grupie dzieci z jąkaniem. Przedstawiono im krótką, dopasowaną do ich możliwości poznawczych prezentację na temat mobbingu. Zawierała ona podstawowe informacje o mobbingu szkolnym, wyjaśnienie, dlaczego to nie ofiara jest winna przemocy, gdzie dzieci i rodzice mogą szukać pomocy, strategie reagowania na zaczepne zachowania, dostosowane do sytuacji i możliwości dziecka $\mathrm{z}$ jąkaniem. Dobór informacji w prezentacji miał na celu uwrażliwienie dzieci na przemoc szkolną, uświadamianie o szkodliwości zjawiska, poinformowanie o tym, jak i gdzie szukać skutecznej pomocy. Celem prezentacji było także wyposażenie uczestników w wiedzę o technikach radzenia sobie 
z mobbingiem szkolnym i odpowiadania na zaczepki. Następnie uczestnicy warsztatów - dzieci, terapeuci i wolontariusze brali udział w grach dramowych. Miały one na celu zastosowanie zdobywanej wiedzy w praktyce, a także oswojenie się dzieci $\mathrm{z}$ trudną tematyką związaną z dokuczaniem. Porównanie odpowiedzi dzieci udzielanych $w$ ankietach rozdanych przed programem i po jego zakończeniu potwierdziło przydatność zastosowania takiej formy wsparcie dziecka z problemem logopedycznym. Znaczna większość uczestniczących w tych warsztatach dzieci potwierdziła, że miała styczność z przemocą w szkole (jako obserwator lub/i ofiara). Przed warsztatami duża część ankietowanych dzieci stwierdzała, że to ofiara jest winna przemocy, po warsztatach wszyscy uczestnicy zaznaczyli, że wina nie leży po stronie ofiary. W pierwszej ankiecie większość uczestników oznajmiła, że nie wie, do kogo zwrócić się o pomoc w sytuacji przemocy, po warsztatach dzieci wskazywały na rodziców i nauczycieli. Na zakończenie tego programu dzieci nabyły wiedzę na temat tego, jak reagować na zaczepki, jak uzyskiwać pomoc czy jak zachować się w sytuacji, gdy jest się świadkiem mobbingu, podczas gdy przed warsztatami nie miały wiedzy na ten temat. Na zakończenie warsztatów zarówno dorośli, jak i dzieci deklarowali wzrost poczucia sprawstwa w związku z dokuczaniem z powodu jąkania, obniżenie poziomu lęku i uczucia bezradności.

Dyskusje przeprowadzone na podsumowanie tych warsztatów w obu grupach - dzieci i rodziców - potwierdziły, że podejmowanie tego typu działań edukacyjnych w przypadku jąkania jest niezwykle istotne. Dzieci zmagające się z problemami w komunikowaniu się w sytuacji mobbingu często czują się bezbronne, a nawet winne tego, że są jego ofiarami. Bardzo często boją się prosić o pomoc osobę dorosłą. Pozostawione same sobie zmagają się ze skutkami wynikającymi z tego niebezpiecznego zjawiska. Długotrwałe doświadczanie mobbingu może wywierać negatywny wpływ na funkcjonowanie psychospołeczne dziecka, na jego osiągnięcia szkolne, a nawet na stan zdrowia.

\section{Implikacje dla praktyki}

Wyniki badania sondażowego przeprowadzonego w grupie logopedów oraz nauczycieli, a także obserwacje poczynione podczas wdrażania programu antymobbingowego w grupie dzieci jąkających się i ich rodziców potwierdzają tezę, że istotne jest podniesienie świadomości logopedów i nauczycieli na temat zjawiska mobbingu szkolnego. Skuteczna opieka nad uczniami zmagającymi się z problemami w komunikowaniu się bez wdrażania w placówkach edukacyjnych (szkołach, poradniach psychologiczno-pedagogicznych, ale także przedszkolach) różnych form profilaktyki antymobbingowej wydaje się niewykonalna. Podobny wniosek można wysnuć, dokonując krytycznej analizy literatury przedmiotu [Murphy, Quesal, 2002; Yaruss i wsp., 2004; Langevin, 2015]. 
Konkludując, autorki postulują następujące formy aktywności logopedów w tym zakresie:

1) rutynowe rozpoznawanie, czy uczestniczące w terapii logopedycznej dziecko nie jest ofiarą mobbingu szkolnego (rozmowa z uczniem, nauczycielem - wychowawcą klasy, pedagogiem szkolnym, a także - o ile to konieczne - $\mathrm{z}$ rodzicami dziecka) ${ }^{2}$;

2) współudział we wdrażaniu na terenie placówek edukacyjnych kampanii profilaktycznych związanych z mobbingiem szkolnym (plakaty lub ulotki, specjalne dni lub godziny wychowawcze poświęcone na analizę zjawiska, dodatkowe szkolenia dla nauczycieli, telefony kontaktowe, prelekcje dla rodziców i personelu szkolnego), które miałby na celu rekomendowanie różnych strategii antymobbingowych;

3) organizowanie na terenie szkół warsztatów dla uczniów, promujących treści związane z dobrą komunikacją, tolerancją i akceptacją dla inności - najlepiej z aktywnym udziałem ucznia, który korzysta z terapii logopedycznej; ich celem powinno być między innymi upowszechnianie wiedzy na temat różnych zaburzeń w komunikowaniu się oraz promujących wartości antydyskryminacyjne i edukację włączającą [Scott, Guitar, 2012; Węsierska, Krawczyk, 2017]³.

Niezwykle ważne jest również udzielenie bezpośredniego wsparcia dziecku zmagającemu się z mobbingiem szkolnym, aby czuło się ono bezpiecznie w placówce i mogło zaufać nauczycielowi. Logopeda, $\mathrm{z}$ racji bardziej indywidualnych relacji $\mathrm{z}$ dzieckiem, może być w tych działaniach osobą bardzo wspierającą. Należy przypuszczać, że skuteczne wdrażanie różnych form prewencji nie będzie możliwe bez podjęcia działań w zespołach składających się zarówno z nauczycieli, jak i pedagogów szkolnych, psychologów oraz logopedów, z aktywnym udziałem rodziców. Budowanie wspierającego dziecko środowiska, którego osią jest swoisty team terapeutyczny złożony z nauczyciela, logopedy i rodziców ucznia może znacząco przyczynić się do poprawy funkcjonowania na terenie szkoły uczniów zmagających się z zaburzeniami w komunikowaniu się.

\footnotetext{
2 W tym celu można wykorzystać polską adaptację testu autorstwa Marylin Langevin [2013], dostępną na stronie http://centrumlogopedyczne.com.pl/narzedzia/

3 Przykład zajęć warsztatowych dla uczniów i nauczycieli, podczas których upowszechniana jest wiedza o jąkaniu, a także treści związane z zapobieganiem mobbingowi szkolnemu, można znaleźć w Boroń i wsp., 2019, s. 30-34.
} 
Literatura

Blood G., Boyle M., Blood I., Nalesnik G., 2010, Bullying in children who stutter. Speech language pathologists' perceptions and intervention strategies, „Journal of Fluency Disorders”, vol. 35(2), s. 92-109.

Boroń A., Michta A., Sakwerda A., Węsierska K., 2019, Zajęcia z pomysłem. Scenariusz warsztatów dla nauczycieli. Scenariusz warsztatów dla uczniów, „Forum Logopedy”, nr 31, s. 30-34.

Card N.A., Hodges E.V., 2008, Peer victimization among school children: correlations, causes, consequences, and considerations in assessment and intervention, „School Psychology Quarterly", vol. 23(4), s. 451-461.

Dambach K.E., 2003, Mobbing w szkole: jak zapobiegać przemocy grupowej, Gdańsk: Gdańskie Wydawnictwo Psychologiczne.

Davis S., Howell P., Cooke F., 2002, Sociodynamic relationships between children who stutter and their non-stuttering classmates, „Journal of Child Psychology and Psychiatry”, no. 43, s. 939-947.

Erickson S., Block S., 2013, The social and communication impact of stuttering on adolescents and their families, „Journal of Fluency Disorders”, vol. 38(4), s. 311-324.

Gebauer K., 2007, Mobbing w szkole, Warszawa: Instytut Wydawniczy PAX.

Greene R., 2014, Trudne emocje u dzieci. Jak wspólnie rozwiązywać problemy w domu i w szkole, Warszawa: Wydawnictwo Edgard.

Hershkowitz I., Lamb M.E., Horowitz D., 2007, Victimization of Children with Disabilities, „American Journal of Orthopsychiatry”, vol. 77(4), s. 629-635.

Kuros K., Węsierska K., 2013, Rola nauczyciela w promowaniu dobrej komunikacji w środowisku szkolnym, [w:] E. Kochanowska, J. Skibska (red.), Nauczyciel wobec wyzwań wspótczesności. Dylematy, poszukiwania i inspiracje, Bielsko-Biała: Wydawnictwo Naukowe Akademii Techniczno-Humanistycznej, s. 267-277.

Langevin M., 2000, Teasing and Bullying. Unacceptable Behaviour. The TAB Program, Edmonton: Istar.

Langevin M., 2013, Dokuczanie i znęcanie się nad jąkającymi się dziećmi, kwestionariusz dla dzieci, wersja zaktualizowana (Teasing and Bullying Questionnaire for Children Who Stutter - Revised), tłum. K. Węsierska, M. Węsierska, http://centrumlogopedyczne.com.pl/narzedzia/ (dostęp: 16.06.2019).

Langevin M., 2015, Bullying Experienced by Youth Who Stutter. The Problem and Potential Intervention Strategies, [w:] K.O. St. Louis (red.), Stuttering Meets Stereotype, Stigma, and Discrimination. An Overview of Attitude Research, Morgantown: West Virginia University Press, s. 71-90.

Langevin M., Bortnick K., Hammer T., Wiebe E., 1998, Teasing/bullying experienced by children who stutter. Toward development of a questionnaire, „Contemporary Issues in Communication Science and Disorders", vol. 25, s. 12-24.

Langevin M., Packman A., Onslow M., 2010, Parent perceptions of the impact of stuttering on their preschoolers and themselves, „Journal of Communication Disorders”, no. 43, s. 407-423.

Lindsay G., Dockrell J.E., Mackie C., 2008, Vulnerability to bullying in children with a history of specific speech and language difficulties, „European Journal of Special Needs Education”, no. 23 , s. 1-16.

Little L., 2001, Peer victimization of children with Asperger spectrum disorders, „Journal of the Academy of Child and Adolescent Psychiatry", no. 40, s. 995-996.

Little L., 2004, Victimization of children with disabilities, [w:] K.A. Kendall-Tackett (red.), Health consequences of abuse in family. A clinical guide for evidence-based practice, Washington: American Psychological Association, s. 95-108. 
Miller C., Lowen C., 2012, The Essential Guide to Bullying Prevention and Intervention. Protecting Children and Teens from Physical, Emotional, and Online Bullying, New York: Alpha.

Mishna F., 2003, Learning disabilities and bullying. Double jeopardy, „Journal of Learning Disabilities", vol. 36(4), s. 336-347.

Murphy W.P., Quesal R.W., 2002, Strategies for addressing bullying with the school-age child who stutters, „Seminars in Speech and Language”, no. 23, s. 205-211.

O’Moore A.M., Minton S.T., 2008, Jak opanować przemoc w szkole, Warszawa: Wydawnictwa Szkolne i Pedagogiczne.

Olweus D., 1991, Bully/victim problems among school children. Basic facts and effects of a school based intervention program, [w:] D. Pepler, K. Rubin (red.), The development and treatment of childhood aggression, Hillsdale: Erlbaum, s. 411-448.

Olweus D., 2007, Mobbing. Fala przemocy w szkole. Jak ja powstrzymać?, Warszawa: Jacek Santorski $\&$ Co.

Ostrowska K., Surzykiewicz J., 2005, Zachowania agresywne w szkole. Badania porównawcze 1997 i 2003, Warszawa: Centrum Metodyczne Pomocy Psychologiczno-Pedagogicznej.

Plichta P., 2010, Uczniowie niepelnosprawni intelektualnie jako ofiary i sprawcy agresji rówieśniczej - kontekst edukacyjny, [w:] J. Pyżalski, E. Roland (red.), Bullying a specjalne potrzeby edukacyjne. Podręcznik metodyczny, Łódź: Wyższa Szkoła Pedagogiczna w Łodzi/Centrum Badań Behawioralnych Uniwersytetu Stavanger, moduł 6.

Pyżalski J., 2012, Agresja elektroniczna i cyberbullying jako ryzykowne zachowania młodzieży, Kraków: Oficyna Wydawnicza Impuls.

Rigby K., 2010, Przemoc w szkole. Jak ją ograniczać. Poradnik dla rodziców i pedagogów, Kraków: Wydawnictwo Uniwersytetu Jagiellońskiego.

Savage R., 2005, Friendship and bullying patterns in children attending a language base in a mainstream school, „Education Psychology in Practice”, no. 21, s. 23-36.

Scott L., Guitar C., 2012, Jak mówić w szkole o jąkaniu? Podręcznik dla nauczycieli i logopedów, Katowice: Centrum Logopedyczne.

Smith P.K., Pepler D., Rigby K. (red.), 2004, Bullying in Schools. How Successful Can Intervention $B e$ ?, Cambridge: Cambridge University Press.

Way B., 1990, Drama w wychowaniu dzieci i młodzieży, Warszawa: Wydawnictwa Szkolne i Pedagogiczne.

Węsierska K., 2012, Profilaktyka logopedyczna w ujęciu systemowym, [w:] Węsierska K. (red.), Profilaktyka logopedyczna w praktyce edukacyjnej, t. 1, Katowice: Wydawnictwo Uniwersytetu Śląskiego, s. 25-47.

Węsierska K., Gacka E., Langevin M., Węsierska M., 2015, Sytuacja szkolna dzieci jąkających się $w$ Polsce - wstępne wyniki badań i strategie pomocy, [w:] K. Węsierska (red.), Zaburzenia płynności mowy: teoria i praktyka, t. 1, Katowice: Komlogo - Uniwersytet Śląski, s. 221-236.

Węsierska K., Krawczyk A., 2017, Wsparcie dziecka jąkającego się w środowisku edukacyjnym, [w:] K.I. Bieńkowska, I. Marczykowska, A. Myszka (red.), Głos - Język - Komunikacja 4. Funkcjonowanie społeczne dzieci z problemami komunikacyjnymi, Rzeszów: Wydawnictwo Uniwersytetu Rzeszowskiego, s. 13-30.

Yaruss J.S., Murphy W.P., Quesal R.W., Reardon N.A., 2004, Bullying and teasing: Helping children who stutter, New York: National Stuttering Association. 
Streszczenie

$\mathrm{W}$ artykule zaprezentowano wyniki dwóch projektów badawczych dotyczących mobbingu szkolnego wobec uczniów z zaburzeniami w komunikowaniu się. Celem pierwszego projektu było sondowanie opinii nauczycieli $(n=53)$ i logopedów $(n=59)$ na temat częstości występowania tego zjawiska, jego przyczyn oraz potencjalnych środków zaradczych. Respondenci byli również proszeni o ocenę, czy dzieci zmagające się z jakimkolwiek problemem logopedycznym częściej stają się ofiarami dokuczania i/lub znęcania w szkole. Rozpoznawano także opinie badanych na temat potencjalnych form przeciwdziałania mobbingowi szkolnemu oraz ich przygotowania do radzenia sobie z tym zjawiskiem na terenie szkoły. W opracowaniu przedstawiono również wyniki pilotażowego projektu badawczego realizowanego w ramach spotkań warsztatowych dla dzieci jąkających się i ich rodzin, organizowanych na Uniwersytecie Śląskim w Katowicach. Podczas tych warsztatów przeprowadzono zajęcia edukacyjne z zakresu praktycznych aspektów radzenia sobie z mobbingiem szkolnym. W warsztatach wzięły udział zarówno dzieci jąkające się, jak i ich rodzice/opiekunowie. Autorki omówiły również wyniki sondażu przeprowadzonego wśród uczestników przed warsztatami i po ich wdrożeniu na temat mobbingu szkolnego i potencjalnych strategii radzenia sobie z tym zjawiskiem. W podsumowaniu artykułu zarekomendowano przykładowe formy wsparcia ucznia w radzeniu sobie z przejawami dokuczania lub/i prześladowania w szkole.

\section{Abstract}

The article presents the findings from two research projects on bullying among students with communication disorders. The aim of the first project is to survey the opinions of teachers $(n=53)$ and speech-language therapists/pathologists $(n=59)$ on the prevalence of this phenomenon, its causes and potential remedies. Respondents were also asked whether children with speech-language problems were more likely to become victims of bullying at school in their opinion. The study also accounts for the respondents' opinions of potential forms of preventing bullying and preparing students for dealing with this problem in the school setting. In addition, the article presents the results of a pilot study carried out in the framework of workshop meetings organized at the University of Silesia in Katowice. During these workshops, educational activities were carried out with regard to the practical aspects of how to deal with bullying at school. The workshops involved both stuttering children and their parents/caregivers. The authors also discuss the results of a survey conducted among the workshop participants in the form of pre- and post-workshop questionnaires. The paper also includes evaluation of issues such as, bullying at school and potential strategies of dealing with it. The final part of the article, provides examples of strategies of how to support students in dealing with bullying in schools. 